\title{
Evaluating Electrocoagulation and Chemical Coagulation for Removing Dissolved Silica from High Efficiency Reverse Osmosis (HERO) Concentrate Solutions
}

\author{
Yingying Chen, James C. Baygents, James Farrell* \\ Department of Chemical and Environmental Engineering \\ University of Arizona, Tucson, AZ 85721
}

*corresponding author: farrellj@email.arizona.edu; 520 940-0487

(c) 2016. This manuscript version is made available under the Elsevier user license http://www.elsevier.com/open-access/userlicense/1.0/ 


\section{ABSTRACT}

High efficiency reverse osmosis (HERO) produces high $\mathrm{pH}$ concentrate streams that often contain high levels of dissolved silica. Removal of silica from these concentrate streams is desirable before brine concentration and crystallization. This research investigated removal of dissolved silica from simulated HERO concentrate solutions using electrocoagulation (EC) with mild steel anodes and chemical coagulation with $\mathrm{FeCl}_{3}$. At $\mathrm{pH}$ values of above 10, the mild steel anodes immediately passivated and were not able to deliver $\mathrm{Fe}^{2+}$ ions into the solution. This necessitated lowering the solution $\mathrm{pH}$ value via $\mathrm{HCl}$ or $\mathrm{FeCl}_{3}$ addition prior to $\mathrm{EC}$. At $\mathrm{pH}$ values $\leq 10$, iron dosing by $\mathrm{EC}$ was in agreement with that given by Faraday's law. The optimal initial $\mathrm{pH}$ value for operating the EC process was 8 , which required addition of $17.8 \mathrm{mM} \mathrm{HCl}$ or $5.8 \mathrm{mM} \mathrm{FeCl}_{3}$. An EC iron dose of 4.0 $\mathrm{mM}$ resulted in 76-89\% silica removal for solutions with initial $\mathrm{pH}$ values between 4 and 8 . Higher dosing up to $9.3 \mathrm{mM}$ increased silica removal by only $5 \%$. Chemical coagulation was not as effective as $\mathrm{EC}$, and was able to achieve a maximum removal of $64 \%$ with a $4.0 \mathrm{mM} \mathrm{FeCl}{ }_{3}$ dose. Solution ionic strength had no measurable impact on silica removal by $\mathrm{EC}$, but did affect final solution $\mathrm{pH}$ values and silica removal by chemical coagulation. For both EC and chemical coagulation, the initial $\mathrm{pH}$ value of solution had greater impact on silica removal than the iron dose.

Keywords: High efficiency reverse osmosis (HERO) Concentrate, silica removal, electrocoagulation, chemical coagulation, iron 


\section{INTRODUCTION}

High efficiency reverse osmosis (HERO) is becoming increasingly utilized for water desalination, especially for treating waters containing high levels of dissolved silica [1,2]. In the HERO process, the feed water to the $\mathrm{RO}$ unit is raised to a $\mathrm{pH}$ value $\geq 9$. This has the effect of greatly reducing fouling of the RO membrane, and has been found to allow permeate recoveries as high as $99 \%$ [3]. The first step in a HERO process involves removal of $\mathrm{Ca}^{2+}$ and $\mathrm{Mg}^{2+}$ ions using weak acid cation exchange (WAC) media. The second step removes dissolved $\mathrm{CO}_{2}$. Decarbonation reduces the buffering capacity of the water, thereby decreasing the amount of $\mathrm{NaOH}$ required to raise the $\mathrm{pH}$. Next, $\mathrm{NaOH}$ is added to raise the $\mathrm{pH}$ to $\geq 9$ before it enters the $\mathrm{RO}$ unit. During the $\mathrm{RO}$ treatment step, the $\mathrm{pH}$ of the concentrate increases to $\sim 11-11.2$, which is the highest $\mathrm{pH}$ allowable for continuous duty of most RO membranes $[4,5]$. Because of high membrane rejection of ions, including $\mathrm{OH}^{-}$, the permeate $\mathrm{pH}$ decreases to $~ 8.5$ [3]. The softening of the water and decarbonation prevents carbonate scale from forming on the membrane. The elevated $\mathrm{pH}$ converts dissolved silica into anionic form (e.g., $\mathrm{H}_{3} \mathrm{SiO}_{4}{ }^{-}$), and also results in formation of a negative charge on the $\mathrm{RO}$ membrane surface. The negative charge on the membrane prevents fouling by colloidal material, dissolved silica and dissolved organic matter, which are also negatively charged at elevated $\mathrm{pH}$ values. In addition, the high $\mathrm{pH}$ on the concentrate side of the $\mathrm{RO}$ membrane prevents biofouling via both biocidal and electrostatic effects [6].

The HERO process was developed for treating groundwater containing high levels of dissolved silica, and HERO systems have been observed to operate with silica levels in the concentrate stream as high as $1500 \mathrm{mg} / \mathrm{L}$ without membrane fouling [2]. The high concentration of silica in HERO 
concentrate solutions results in precipitation fouling of surfaces in piping systems and tanks when the high $\mathrm{pH}$ solutions are neutralized during brine treatment. Because of their unique properties, HERO concentrate streams are difficult to treat by conventional brine treatment methods, such as lime softening, brine concentrators or thermal crystallization [7]. HERO concentrate streams contain primarily alkali metal cations, mono- and divalent anions, and dissolved silica. Thus, the main challenge in treating these concentrates is removing high levels of dissolved silica from high $\mathrm{pH}$ solutions containing only monovalent cations. With only monovalent cations present, the electrical double layers on negatively charged flocculating particles are considerably expanded compared to those in solutions containing divalent and trivalent cations [8].

Commonly used methods for removing dissolved silica from solution include: adsorption on activated alumina, coagulation with iron and aluminum salts, and ion exchange, for high $\mathrm{pH}$ solutions. Adsorption and ion exchange produce regenerant brine solutions that would not solve the silica disposal problem. Thus, coagulation processes are the best treatment option for removing silica from HERO concentrate solutions. Several previous studies have found that dissolved silica can be removed from solution using either chemical coagulation or electrocoagulation (EC) using $\mathrm{Fe}^{3+}$ or $\mathrm{Al}^{3+}$ ions $[9,10,11,12,13,14,15,16]$. Because $\mathrm{Al}^{3+}$ coagulation processes are less effective at $\mathrm{pH}$ values greater than 8 , coagulation processes based on $\mathrm{Fe}^{3+}$ are preferred in high $\mathrm{pH}$ solutions [17]. Dissolved silica removal using iron coagulating agents can involve co-precipitation of ferric-silicate solids or involve silica adsorption to ferric hydroxide precipitates. Silica adsorption to ferric hydroxide is a chemical adsorption process where Fe-O-Si bonds form via a ligand exchange reaction [18]. These reactions involve replacement of $-\mathrm{OH}$ or $-(\mathrm{OH})_{2}$ ligands bound to $\mathrm{Fe}(\mathrm{III})$ with a silicate 
anion. Monodentate complexes involve formation of a single $\mathrm{Fe}-\mathrm{O}-\mathrm{Si}$ bond, and bidentate complexes involve formation of two Fe-O-Si bonds to a single Fe(III) atom (bidentate mononuclear), or to two adjacent Fe(III) atoms (bidentate binuclear) [18].

One challenge in using EC to treat HERO concentrate solutions is passivation of the anode at high $\mathrm{pH}$ values [19]. Passivation of iron anodes in highly alkaline solutions results from the low solubility of ferrous ions that result in an insoluble $\mathrm{Fe}(\mathrm{OH})_{2}$ layer on the anode surface that inhibits $\mathrm{Fe}^{2+}$ atoms from entering the solution. This causes an increase in the electrode voltage required to maintain the desired current density. At elevated anode voltages, water oxidation and evolution of $\mathrm{O}_{2}$ gas become thermodynamically favorable, and $\mathrm{O}_{2}$ evolution competes with iron oxidation as the anode reaction. This may result in iron dosing that is below that corresponding to Faraday's law. Thus, electrode passivation may cause problems with coagulant dosing when treating HERO concentrate solutions.

The goal of this research was to investigate the effectiveness of EC and chemical coagulation for removing dissolved silica from simulated HERO concentrate solutions. The effect of solution $\mathrm{pH}$

value on $\mathrm{Fe}^{2+}$ dosing was investigated to determine the ability of $\mathrm{EC}$ to deliver $\mathrm{Fe}^{2+}$ ions in accord with Faraday's law in high pH solutions. Batch experiments measuring dissolved silica removal were performed with varying doses of $\mathrm{Fe}^{3+}$, delivered by $\mathrm{EC}$ or via addition of $\mathrm{FeCl}_{3}$. The effect of the initial solution $\mathrm{pH}$ value and solution ionic strength on silica removal was determined.

\section{MATERIALS AND METHODS}

Test solutions were prepared by dissolving sodium metasilicate, $\mathrm{Na}_{2} \mathrm{SiO}_{3} \bullet 9 \mathrm{H}_{2} \mathrm{O}$, (Sigma-Aldrich) in simulated RO concentrate solutions or in ultrapure water (UPW) $(0.18 \mu \mathrm{S} / \mathrm{cm})$ to produce solutions 
with ionic strengths (IS) of 55.6 and $16.7 \mathrm{mM}$. The compositions of the two test solutions are listed in Table 1. A dissolved silica concentration of $1000 \mathrm{mg} / \mathrm{L}$ as $\mathrm{SiO}_{2}$ was selected to simulate a HERO process with $30 \mathrm{mg} / \mathrm{L}$ of silica in the feed water operated at a water recovery of $97 \%$. The simulated RO concentrate was based on that produced in a previous investigation treating Central Arizona Project water, as delivered to Tucson, Arizona [20]. The test solutions prepared in UPW were used to investigate the effect of solution IS on silica removal. Natural organic matter was not included in the test solutions, since HERO is primarily used for treating groundwaters that often contain little or no organic matter. Prior to the chemical or electrocoagulation experiments, the initial solution $\mathrm{pH}$ values were adjusted to span the range from 12 to 2 by addition of analytic grade $\mathrm{HCl}$ or $\mathrm{NaOH}$. Dissolved silica and iron concentrations were measured using an Agilent model 5100 synchronous vertical dual view inductively coupled plasma optical emission spectrophotometer (ICP-OES). Solution phase speciation of ions was modeled using the PHREEQC modeling package from the U.S. Geological Survey [21,22].

Chemical coagulation experiments were performed in $500 \mathrm{~mL}$ of solution contained in glass beakers using laboratory grade anhydrous powdered $\mathrm{FeCl}_{3}(>98.5 \%$, Science Company). A magnetic stir bar was used to stir the solutions at approximately $60 \mathrm{rpm}$ during the $\mathrm{FeCl}_{3}$ dosing. After dosing, the stirring was continued for a period of 2.0 hours. The supernatant solutions were sampled after 0.5 and 24 hours settling time. Except where indicated, samples were filtered using $0.1 \mu \mathrm{m}$ syringe filters. To assess the amount of silica present in filterable colloidal species, selected samples were also taken without filtering.

Electrocoagulation experiments were performed in a rectangular flow-through reactor (Powell 
Water Systems, Centennial Colorado) with nine mild steel electrodes in parallel plate configuration. The electrodes were $3.2 \times 34.0 \times 0.32 \mathrm{~cm}$ with $0.4 \mathrm{~cm}$ interelectrode gaps. With all electrodes in place, the void volume of the reactor was $0.35 \mathrm{~L}$ with a total wetted anode surface area of $900 \mathrm{~cm}^{2}$. Before use, the electrodes were polished with 100 grit sandpaper. The test solutions were fed into the reactor at $0.5 \mathrm{~L} / \mathrm{min}$ yielding a hydraulic detention time of $0.70 \mathrm{~min}$. A current density of $8.0 \mathrm{~mA} / \mathrm{cm}^{2}$ was provided by a Protek model 3005B (30 V, 5 A) galvanostatic power supply. The samples were collected after 10 minutes of steady state operation, which was achieved after passage of 14 reactor volumes of solution through the reactor. Effluent samples from the EC reactor were collected in 125 $\mathrm{mL}$ vials and were shaken for 0.5 hours and then allowed to settle prior to sampling the supernatant solution. The effect of a cationic polymer clarifying agent (6505 HTH Super Concentrated Clarifier, Arch Chemicals, Inc.) on the settling properties of the flocs was investigated by dosing selected samples with concentrations ranging from $0.05 \%$ to $1 \%$.

Iron dosing rates were measured by placing a single anode and single cathode in the EC reactor. Solutions with the desired $\mathrm{pH}$ value were circulated through the reactor while the electrodes were galvanostatically polarized at current densities ranging from 1.0 to $9.0 \mathrm{~mA} / \mathrm{cm}^{2}$. The same set of two electrodes was used for all dosing rate experiments. Loss of iron from the anode was measured gravimetrically by weighing before and after polarization periods ranging from 1 to 5 hours. 
Table 1. Composition of the low and high IS test solutions.

\begin{tabular}{|c|c|c|c|}
\hline Feed water & Analyte & $\begin{array}{c}\text { Concentration } \\
(\mathrm{mM})\end{array}$ & $\begin{array}{c}\text { Concentration } \\
(\mathrm{mg} / \mathrm{L})\end{array}$ \\
\hline \multirow{3}{*}{ UPW } & \multirow{3}{*}{$\begin{array}{c}\mathrm{Na}^{+} \\
\mathrm{SiO}_{2} \\
\text { Ionic strength } \\
(@ \mathrm{pH}=7)\end{array}$} & 33.3 & 766 \\
\hline & & 16.6 & 1000 \\
\hline & & 16.7 & \\
\hline \multirow{5}{*}{$\begin{array}{c}\text { Simulated } \\
\text { RO } \\
\text { Concentrate }\end{array}$} & \multirow{5}{*}{$\begin{array}{c}\mathrm{Na}^{+} \\
\mathrm{SiO}_{2} \\
\mathrm{Cl}^{-} \\
\mathrm{SO}_{4}{ }^{2-} \\
\text { Ionic strength } \\
(@ \mathrm{pH}=7)\end{array}$} & 64.7 & 1490 \\
\hline & & 16.6 & 1000 \\
\hline & & 11.3 & 400 \\
\hline & & 10.1 & 967 \\
\hline & & 55.6 & \\
\hline
\end{tabular}

\section{RESULTS AND DISCUSSION}

\subsection{EC Dosing Experiments}

The first objective of this research was to investigate the effect of solution $\mathrm{pH}$ value on the dosing of iron into the solutions. Figure 1 shows the iron dosing rate per unit area of anode surface as a function of the current density for solutions with $\mathrm{pH}$ values ranging from 5 to 12 . The dosing rates $\left(D_{s}\right)$ for solution $\mathrm{pH}$ values of 5, 7, 9 and 10 were in good agreement with that predicted by Faraday's law, as given by:

$$
D_{S}\left(\frac{\mu m o l}{c m^{2} \min }\right)=\frac{i}{F \times z} \times \frac{1000 \mu A}{m A} \times \frac{60 s}{\min }
$$

where $\mathrm{F}$ is the Faraday constant $(96,495 \mathrm{C} / \mathrm{mol}), \mathrm{z}$ is the charge on $\mathrm{Fe}^{2+}$, and $i$ is the current density in $\mathrm{mA} / \mathrm{cm}^{2}$. This indicates that the reaction:

$$
F e_{(s)} \rightarrow F e_{(a q)}^{2+}+2 e^{-}
$$

accounted for nearly all the anodic current. For $\mathrm{pH}$ values of 11 and 12, only trace amounts of iron were released into solution at any current density. Electrode passivation occurred immediately upon 
anodic polarization, and is thereby different from slower passivation processes that are amenable to reversal via changing the electrode polarity [10]. Thus, in cases where HERO produces concentrate solutions with $\mathrm{pH}$ values of 11 or greater, the $\mathrm{pH}$ needs to be lowered in order to use EC for delivering the iron coagulant.

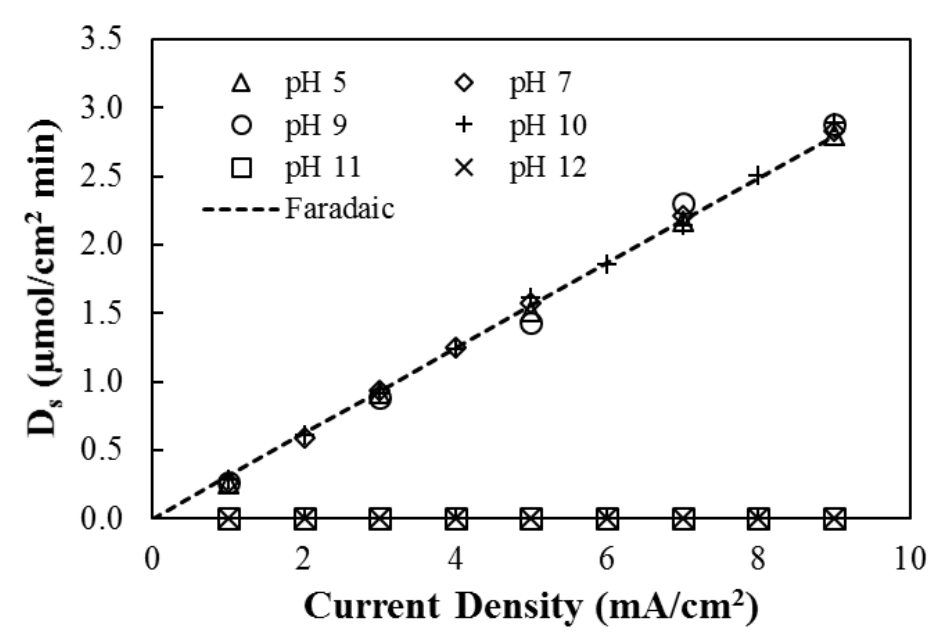

Figure 1. Iron dosing rate as a function of applied current density in solutions with $\mathrm{pH}$ values ranging from 5 to 12 .

In order to allow $\mathrm{Fe}$ dosing via $\mathrm{EC}$, the $\mathrm{pH}$ values of the simulated HERO concentrate solutions were lowered by adding either $\mathrm{HCl}$ or $\mathrm{FeCl}_{3}$. Figure 2 shows how the dose of $\mathrm{HCl}$ and $\mathrm{FeCl}_{3}$ affected the $\mathrm{pH}$ value of the test solutions. To lower the $\mathrm{pH}$ value from 11 to 8 required an $\mathrm{HCl}$ dose of 17.8 $\mathrm{mM}$. This high dose can be attributed to the high buffering capacity of the solution. The dominant species of dissolved silica in the solution at $\mathrm{pH}=11$ was the orthosilicate anion, $\mathrm{H}_{3} \mathrm{SiO}_{4}{ }_{4}$, since $\mathrm{H}_{4} \mathrm{SiO}_{4}$ has a pKa value of 9.9 [23]. Given the total dissolved silica concentration of $16.6 \mathrm{mM}$, the stoichiometric amount of acid required to change the $\mathrm{pH}$ from 11 to 8 is $16.4 \mathrm{mM}$. This is close to the experimentally measured amount of $17.8 \mathrm{mM}$. The dose of $\mathrm{FeCl}_{3}$ required to lower the $\mathrm{pH}$ from 
11 to 8 was $5.83 \mathrm{mM}$, which is $5 \%$ greater than the stoichiometric amount of $5.53 \mathrm{mM}$ if all the iron formed $\mathrm{Fe}(\mathrm{OH})_{3}$.

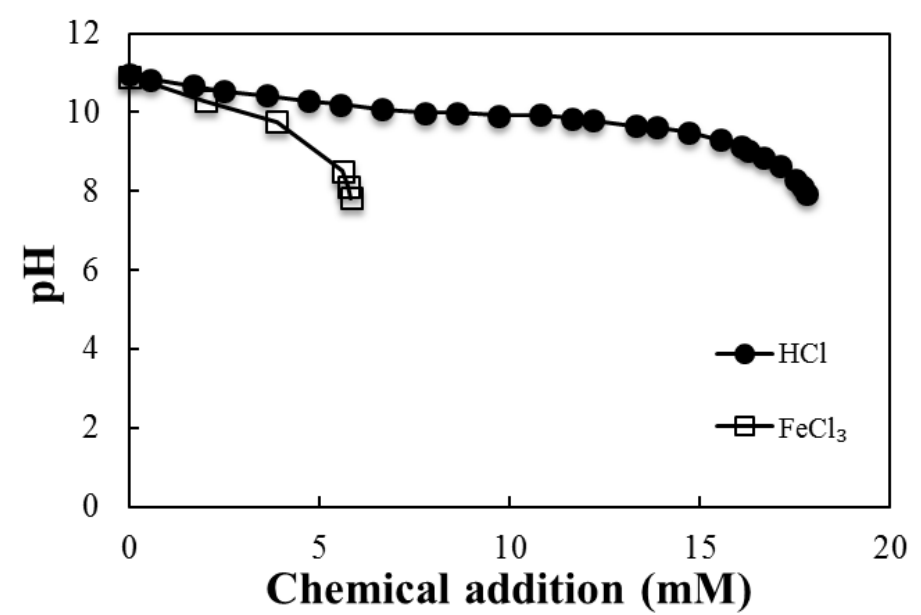

Figure 2. The effect of $\mathrm{HCl}$ or $\mathrm{FeCl}_{3}$ addition on the $\mathrm{pH}$ value of $1000 \mathrm{mg} / \mathrm{L} \mathrm{SiO}_{2}$ solutions with $\mathrm{IS}=16.7 \mathrm{mM}$.

\subsection{Electrocoagulation}

The effectiveness of EC for removing dissolved silica from solutions with different initial $\mathrm{pH}$ values is shown in Figure $3 \mathrm{a}$ as a function of the initial $\mathrm{pH}$ value. Figure $3 \mathrm{~b}$ shows the same silica removal data as a function of the final $\mathrm{pH}$ value. Except for the Fe dose of $9.8 \mathrm{mM}$, the initial $\mathrm{pH}$ values were adjusted down from 11 using $\mathrm{HCl}$. For iron doses of $4.0 \mathrm{mM}, \mathrm{SiO}_{2}$ removals between $76 \%$ and $89 \%$ were observed for initial $\mathrm{pH}$ values between 8 and 4 in both the low and high IS solutions. The similar removal in both the $\mathrm{IS}=16.7$ and $\mathrm{IS}=55.6$ solutions indicates that silica removal was not significantly affected by the solution IS. The ratio of Si atoms removed per Fe atom precipitated was $2.2 \pm 0.1$ for final solution $\mathrm{pH}$ values between 8 and 4 .

The optimal initial $\mathrm{pH}$ range using a $4.0 \mathrm{mM}$ Fe dose was 7-8. At this initial $\mathrm{pH}$, a high level of silica removal was achieved (86-89\%) while also minimizing the required $\mathrm{HCl}$ dose. The higher 
silica removal at a final $\mathrm{pH}$ of 8 as compared to $\mathrm{pH}$ values of 9 and 10 can be attributed to electrostatic effects. At $\mathrm{pH}$ values of 9 and 10, the ferric hydroxide precipitate has a net negative charge [24]. This reduces adsorption of $\mathrm{H}_{3} \mathrm{SiO}_{4}{ }^{-}$, which becomes the predominant silica species at $\mathrm{pH}$ values greater than 9.9. The decreasing silica removal with decreasing $\mathrm{pH}$ values below 6 can be attributed to decreasing precipitation of ferric hydroxide with decreasing $\mathrm{pH}$. For the $4.0 \mathrm{mM} \mathrm{Fe}$ dose, the fraction of iron that remained dissolved was $<0.1 \%$ at $\mathrm{pH}=6.1,11 \%$ at $\mathrm{pH}=5.1$, and $89 \%$ at a final $\mathrm{pH}$ value of 3.3

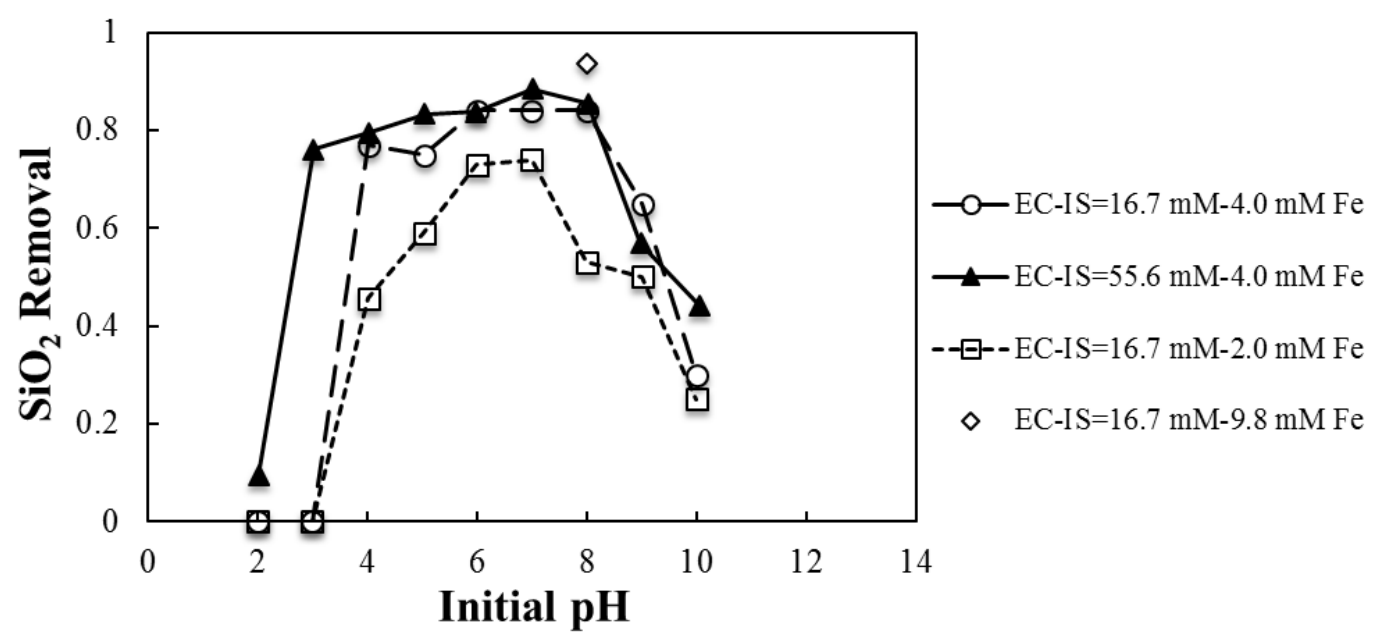

Figure 3a. Removal of silica by EC from solutions with different initial $\mathrm{pH}$ values after 24 hours of settling time. 


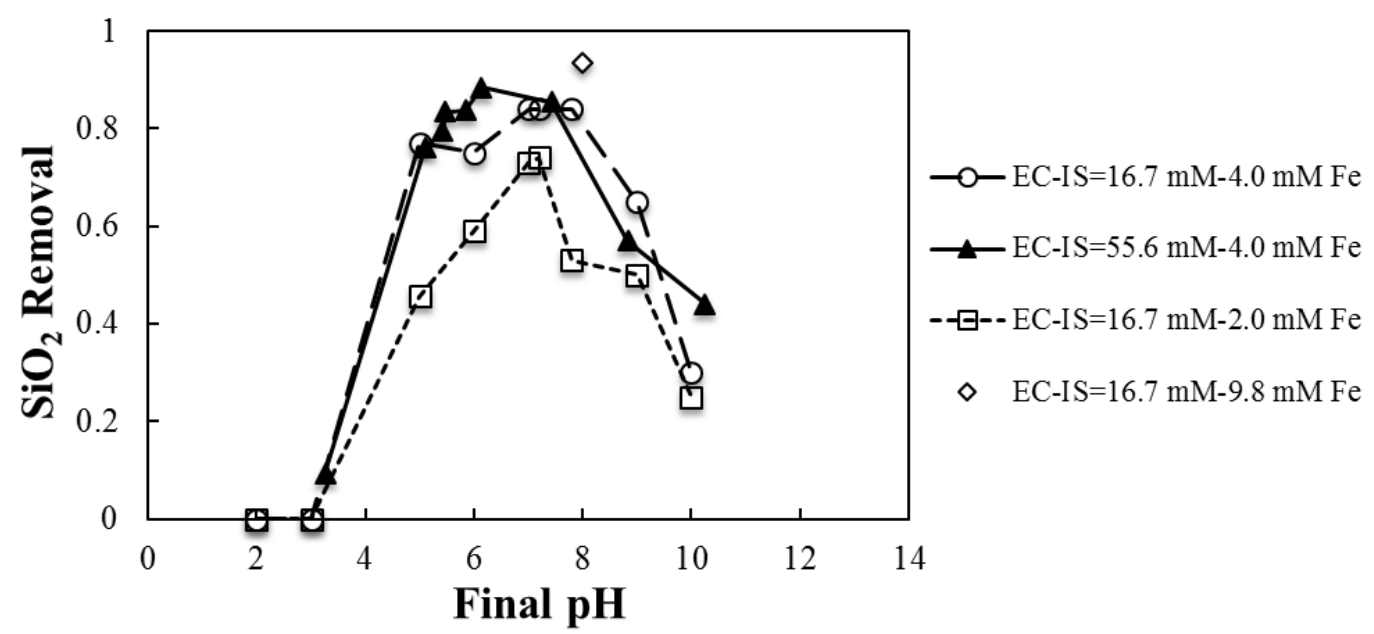

Figure 3b. Removal of silica by EC from solutions with different final $\mathrm{pH}$ values after 24 hours of settling time.

The effect of iron dose is also shown in Figures $3 \mathrm{a}$ and $3 \mathrm{~b}$ for the $\mathrm{IS}=16.7 \mathrm{mM}$ solution. The 2.0 $\mathrm{mM}$ Fe dose resulted in 5-31\% less silica removal than the $4.0 \mathrm{mM}$ dose. Also shown in Figures $3 \mathrm{a}$ and $3 \mathrm{~b}$ is an experiment where the initial $\mathrm{pH}$ value was adjusted to 8 using $5.8 \mathrm{mM} \mathrm{FeCl}$ before adding a $4.0 \mathrm{mM}$ Fe dose using EC. In this experiment the total Fe dose was $9.8 \mathrm{mM}$, but the silica removal was only $5 \%$ greater the $4.0 \mathrm{mM}$ dose. This shows that the initial $\mathrm{pH}$ value affected silica removal by EC more than the Fe dose, and also shows that Fe doses greater than $4.0 \mathrm{mM}$ did not significantly increase silica removal.

Iron dosing by EC had only a small impact on the solution $\mathrm{pH}$ values, as shown in Figure 4. The final solution $\mathrm{pH}$ values for the low ionic strength solutions were within $1 \mathrm{pH}$ unit of the initial value. This can be explained by the fact that acid formed via precipitation of $\mathrm{Fe}(\mathrm{OH})_{3}$ was consumed in the cathode reaction of hydrogen gas evolution $\left(2 H^{+}+2 e^{-} \rightarrow H_{2}\right)$. In the high IS solutions, the final $\mathrm{pH}$ values for solutions with initial $\mathrm{pH}$ values $\leq 4$ were up to $2 \mathrm{pH}$ units greater than the initial value. This can be explained by incomplete precipitation of $\mathrm{Fe}(\mathrm{III})$ at these $\mathrm{pH}$ values. Iron precipitation 
ranged from $94 \%$ for an initial $\mathrm{pH}$ value of 4 , to only $11 \%$ for an initial $\mathrm{pH}$ value of 2 . For the lowest final $\mathrm{pH}$ value of 3. , PHREEQC solution modeling indicated that the Fe(III) remained in solution as $\mathrm{FeSO}_{4}{ }^{+}(1.53 \mathrm{mM}), \mathrm{Fe}(\mathrm{OH})^{2+}(1.11 \mathrm{mM}), \mathrm{Fe}(\mathrm{OH})_{2}{ }^{+}(0.38 \mathrm{mM})$ and $\mathrm{Fe}^{3+}(0.17 \mathrm{mM})$.

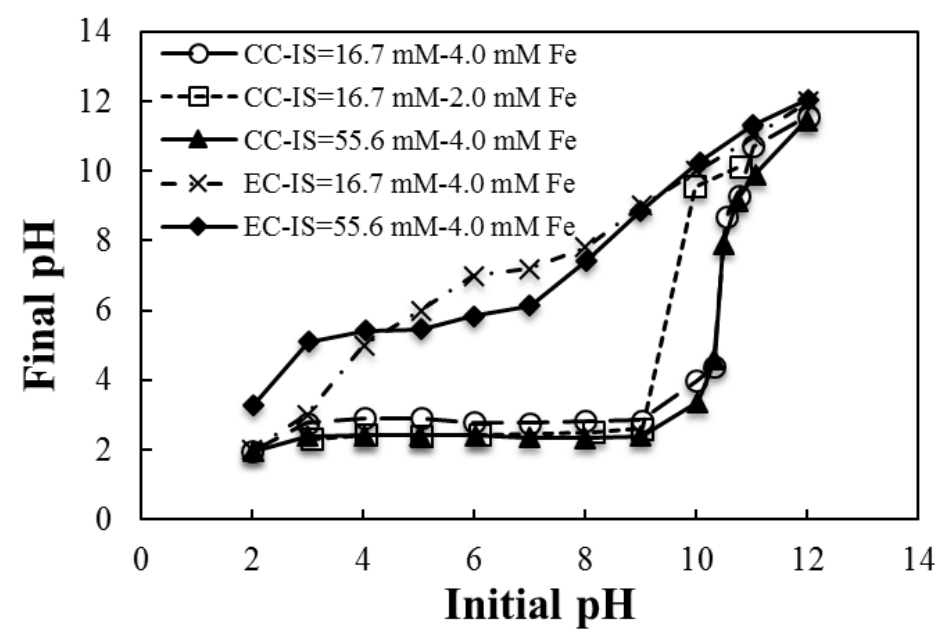

Figure 4. Final solution $\mathrm{pH}$ values versus initial $\mathrm{pH}$ value for $\mathrm{Fe}$ dosing via chemical coagulation (CC) and electrocoagulation (EC).

\subsection{Chemical Coagulation}

Silica removal by chemical coagulation is shown in Figure 5a for solutions with initial $\mathrm{pH}$ values ranging from 12 to 2 . Figure $5 \mathrm{~b}$ shows the same data as a function of the final solution $\mathrm{pH}$ values. Significant silica removal was observed for all experiments for an initial $\mathrm{pH}$ value of 10 . For the 4.0 $\mathrm{mM}$ dose, high levels of silica removal were also observed for initial $\mathrm{pH}$ values between 9 and 5 for the IS=16.7 $\mathrm{mM}$ solution, but not for the IS=55.6 $\mathrm{mM}$ solution. This difference in performance can be attributed to final solution $\mathrm{pH}$ values in the higher ionic strength solution that were 0.4 to $0.5 \mathrm{pH}$ units lower than those for IS=16.7 mM, as shown in Figure 4. Figure 5b shows that the final solution $\mathrm{pH}$ value had a significant effect on the level of silica removal, especially in the $\mathrm{pH}$ range from 2 to 
3.

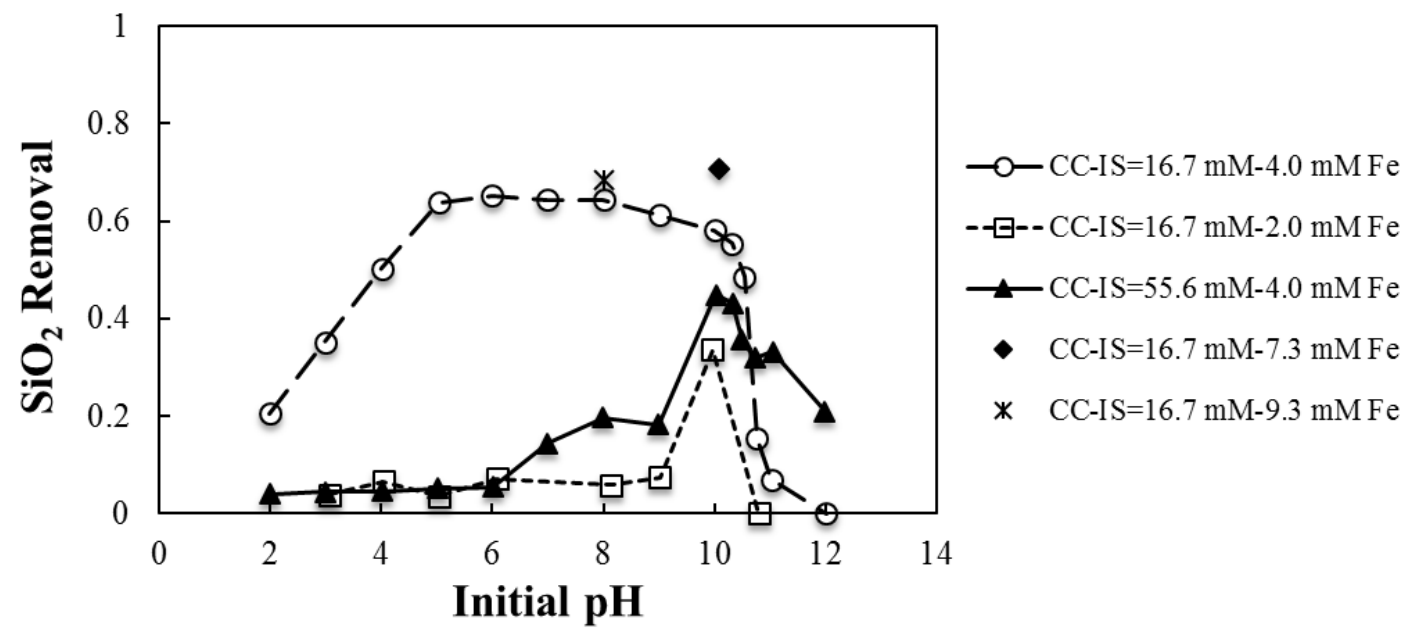

Figure 5a. Removal of silica by chemical coagulation from solutions with different initial $\mathrm{pH}$ values after 24 hours of settling time.

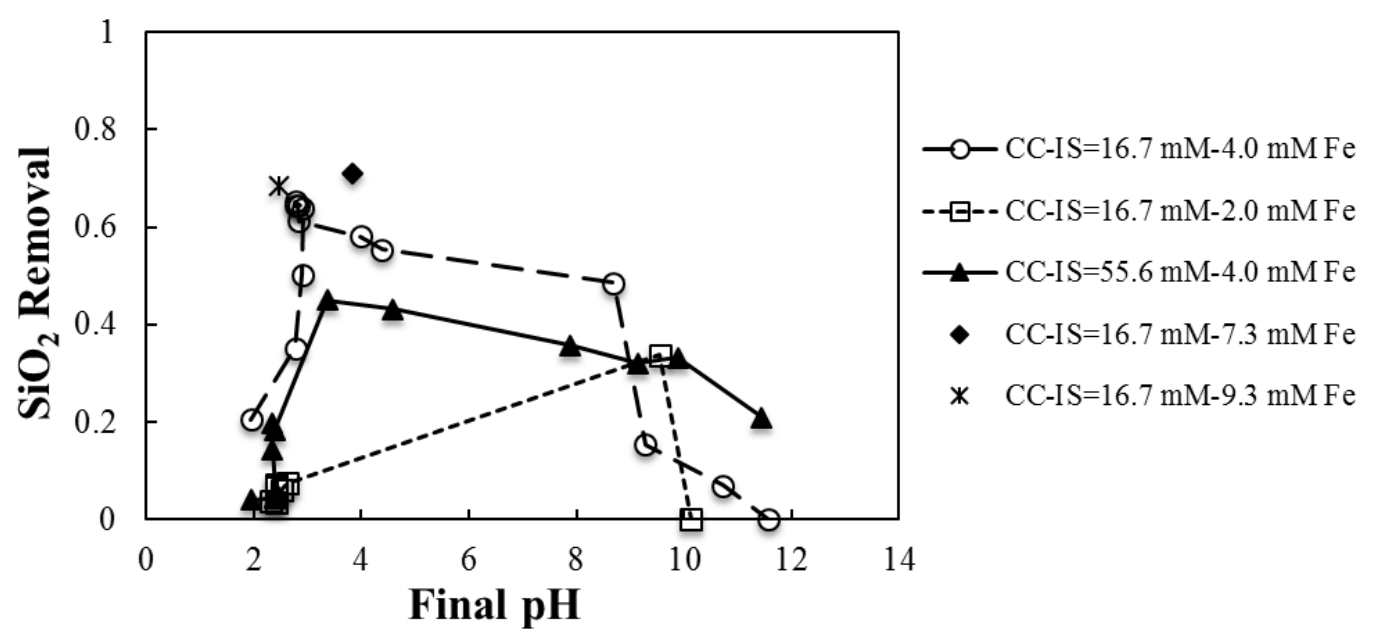

Figure 5b. Removal of silica by chemical coagulation from solutions with different final $\mathrm{pH}$ values after 24 hours of settling time.

Also shown in Figure 5a is silica removal from solutions where the initial $\mathrm{pH}$ was adjusted via $\mathrm{FeCl}_{3}$ addition, rather than $\mathrm{HCl}$ addition. The solution with an initial $\mathrm{pH}$ value of 10 , had $3.3 \mathrm{mM}$ $\mathrm{FeCl}_{3}$ added to reduce the $\mathrm{pH}$ from 11 , followed by addition of a $4.0 \mathrm{mM} \mathrm{FeCl}{ }_{3}$ dose. The resulting $\mathrm{FeCl}_{3}$ dose of $7.3 \mathrm{mM}$ showed similar silica removal as the $4.0 \mathrm{mM}$ dose. Similarly, a solution with a 
total $\mathrm{FeCl}_{3}$ dose of $9.3 \mathrm{mM}$ was achieved via a $5.3 \mathrm{mM}$ dose to reach $\mathrm{pH} 8$, followed by a $4.0 \mathrm{mM}$ dose. This resulted in similar removal as the solution with the $4.0 \mathrm{mM}$ dose where the initial $\mathrm{pH}$ was lowered via $\mathrm{HCl}$ addition. These results indicate that the initial solution $\mathrm{pH}$ value had a greater effect on silica removal than the total $\mathrm{FeCl}_{3}$ dose, and that $\mathrm{FeCl}_{3}$ doses greater than $4.0 \mathrm{mM}$ did not significantly increase silica removal over the $4.0 \mathrm{mM}$ dose.

\subsection{Floc Settling}

The settling behavior of the flocs was investigated by taking filtered and unfiltered samples after 0.5 and 24 hours of settling time. Also investigated was the effect of cationic polymer addition on floc settling. The unfiltered supernatant samples are indicative of silica removal by settled solids. As shown in Figure 6, there was slightly more silica removal by settled solids after 24 hours than after 0.5 hours of settling for all clarifier doses. The difference in silica removal between filtered and unfiltered samples is indicative of filterable colloidal species. For the samples taken after 0.5 hours of settling time, up to $25 \%$ of the initial $1000 \mathrm{mg} / \mathrm{L}$ silica was present as filterable colloids. Combining the silica present as settled solids with the amount present as filterable colloids accounted for 70 to $94 \%$ of the silica. This indicates that there was very little silica present as dissolved silica. The optimal clarifier dose was $0.05 \%$, which is equivalent to $500 \mathrm{mg} / \mathrm{L}$. 


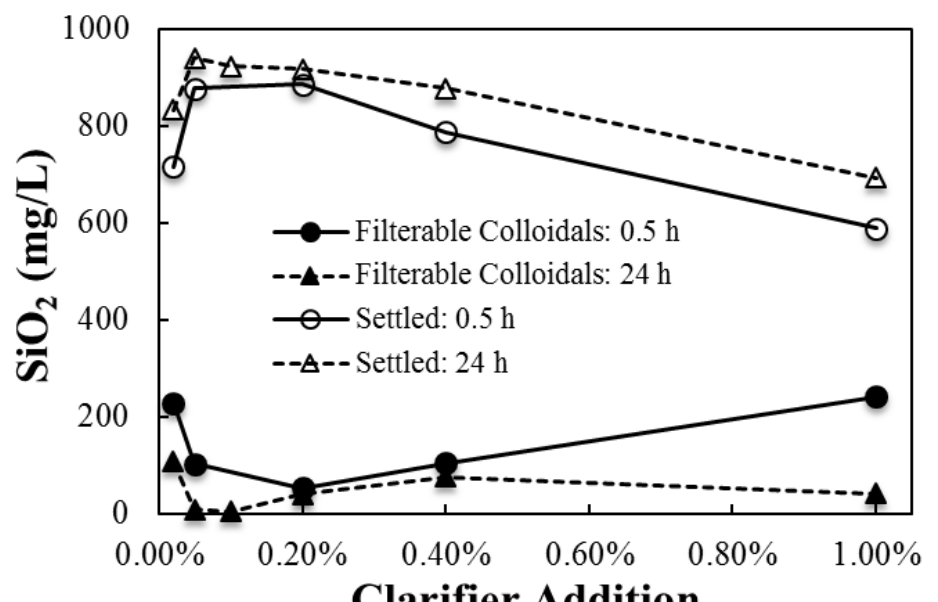

Clarifier Addition

Figure 6. Silica speciation after 0.5 and 24 hours settling time as a function of clarifier dose for a test solution with an initial $\mathrm{pH}$ value of 11 with an EC dose of $9.83 \mathrm{mM} \mathrm{Fe}$.

\section{CONCLUSIONS}

This study indicates that both EC and chemical coagulation are effective for removing dissolved silica from HERO concentrate solutions. The major difference between EC and chemical coagulation was the effect of the coagulant on the final solution $\mathrm{pH}$ value. For $\mathrm{EC}$, the initial solution $\mathrm{pH}$ value was the most important factor affecting the level of silica removal. Initial solution $\mathrm{pH}$ values of 10 or lower were required to avoid immediate passivation of the mild steel anodes. Iron doses of $4.0 \mathrm{mM}$ were slightly more effective than $2.0 \mathrm{mM}$ doses, and gave similar results as iron doses of 7.3 and 9.3 $\mathrm{mM}$. The $4.0 \mathrm{mM}$ dose was able to achieve silica removals ranging from 76 to $89 \%$ for final solutions $\mathrm{pH}$ values between 5 and 7.5. For chemical coagulation, the very high silica concentrations in the test solutions required high doses of $\mathrm{FeCl}_{3}$ that resulted in final solution $\mathrm{pH}$ values that were too low to most effectively remove silica. For chemical coagulation, the optimal $\mathrm{FeCl}_{3}$ dose was also 
4.0 $\mathrm{mM}$, with maximum silica removals ranging from $61-64 \%$ occurring at final solution $\mathrm{pH}$ values near 3.

\section{Acknowledgement}

This research was funded in part by the National Science Foundation (CBET-1235596).

\section{Reference}

[1] D. Mukhopadhyay, S. Whipple, RO system that reduces membrane scaling and fouling tendencies, Ultrapure Water. 14 (1997) 21-30.

[2] J. Thomson, M. Slunjski, M. Fabig, G. Crisp, Potable water HERO process at Yalgoo, Water Pract. Technol. 4 (2009). doi:10.2166/wpt.2009.033.

[3] D. Mukhopadhyay, Method for high efficiency reverse osmosis operation, U.S. Patent Application No. 14/144,423, 2013.

[4] C. Fritzmann, J. Löwenberg, T. Wintgens, T. Melin, State-of-the-art of reverse osmosis desalination, Desalination. 216 (2007) 1-76. doi:10.1016/j.desal.2006.12.009.

[5] J. Kucera, Reverse osmosis: design, processes, and applications for engineers, John Wiley \& Sons, 2015.

[6] T. Nguyen, F.A. Roddick, L. Fan, Biofouling of water treatment membranes: a review of the underlying causes, monitoring techniques and control measures, Membranes. 2 (2012) 804-840. doi: 10.3390/membranes2040804 
[7] A. Subramani, J.G. Jacangelo, Treatment technologies for reverse osmosis concentrate volume minimization: A review, Sep. Purif. Technol. 122 (2014) 472-489. doi:10.1016/j.seppur.2013.12.004.

[8] C.R. O'Melia, Coagulation and Flocculation, Physicochemical Processes for Water Quality Control, W.J. Weber (Eds.), A Wiley-Interscience publication, New York, 1972, pp. 68-69.

[9] Z. Liao, Z. Gu, M.C. Schulz, J.R. Davis, J.C. Baygents, J. Farrell, Treatment of cooling tower blowdown water containing silica, calcium and magnesium by electrocoagulation, Water Sci. Technol. 60 (2009) 2345-2352. doi:10.2166/wst.2009.675.

[10] M.C. Schulz, J.C. Baygents, J. Farrell, Laboratory and pilot testing of electrocoagulation for removing scale-forming species from industrial process waters, Int. J. Environ. Sci. Technol. 6 (2009) 521-526. doi:10.1007/BF03326091.

[11] W. Den, C. Huang, Electrocoagulation for removal of silica nano-particles from chemicalmechanical-planarization wastewater, Colloids and Surf., A: Physicochem. Eng. Asp. 254 (2005) 81-89. doi:10.1016/j.colsurfa.2004.11.026.

[12] C.T. Wang, W.L. Chou, L.S. Chen, S.Y. Chang, Silica particles settling characteristics and removal performances of oxide chemical mechanical polishing wastewater treated by electrocoagulation technology, J. Hazard. Mater. 161 (2009) 344-350. doi:10.1016/j.jhazmat.2008.03.099. 
[13] R. Sheikholeslami, J. Bright, Silica and metals removal by pretreatment to prevent fouling of reverse osmosis membranes, Desalination. 143 (2002) 255-267. doi:10.1016/S00119164(02)00264-3.

[14] G.J. Millar, J. Lin, A. Arshad, S.J. Couperthwaite, Evaluation of electrocoagulation for the pretreatment of coal seam water, J. Water Process Eng. 4 (2014) 166-178. doi:10.1016/j.jwpe.2014.10.002.

[15] N.A. Milne, T. O'Reilly, P. Sanciolo, E. Ostarcevic, M. Beighton, K. Taylor, M. Mullett, A.J. Tarquin, S.R. Gray, Chemistry of silica scale mitigation for RO desalination with particular reference to remote operations, Water Res. 65 (2014) 107-133. doi:10.1016/j.watres.2014.07.010.

[16] S. S. Cob, B. Hofs, C. Maffezzoni, J. Adamus, W.G. Siegers, E.R. Cornelissen, F.E. Genceli Güner, G.J. Witkamp, Silica removal to prevent silica scaling in reverse osmosis membranes, Desalination. 344 (2014) 137-143. doi:10.1016/j.desal.2014.03.020.

[17] M.L. Davis, Water and wastewater engineering, McGraw-Hill, 2010.

[18] X. Gao, R.A. Root, J. Farrell, W. Ela, J. Chorover, Effect of silicic acid on arsenate and arsenite retention mechanisms on 6-L ferrihydrite: A spectroscopic and batch adsorption approach, Appl. Geochemistry. 38 (2013) 110-120. doi:10.1016/j.apgeochem.2013.09.005.

[19] J.Q. Jiang, Study on the anodic passivation of the electrocoagulation in water treatment process, Water Treat. 3 (1986) 344-352. 
[20] M.A. Aghdam, F. Zraick, J. Simon, J. Farrell, S.A. Snyder, A novel brine precipitation process for higher water recovery, Desalination. 385 (2016) 69-74. doi:10.1016/j.desal.2016.02.007.

[21] D.L. Parkhurst, C.A.J. Appelo, Description of input and examples for PHREEQC version 3-a computer program for speciation, batch-reaction, one-dimensional transport, and inverse geochemical calculations, U.S. geological survey techniques and methods. book 6 (2013) 497

[22] D.L. Parkhurst, C.A.J. Appelo, User's guide to PHREEQC (Version 2): A computer program for speciation, batch-reaction, one-dimensional transport, and inverse geochemical calculations, U.S. Department of the Interior, U.S. Geological Survey. (1999).

[23] J.D. Hem, Study and Interpretation the Chemical of Natural of Characteristics Water, U.S. Department of the Interior, U.S. Geological Survey. 2254 (1985) 263.

[24] W. Stumm, Chemistry of the solid-water interface, John Wiley \& Sons, New York, 1992. 